\title{
The mediating effect of self-esteem on emerging adults' materialism and anxiety
}

\author{
Astri Rahmadina, ${ }^{1}$ Fuad Nashori, ${ }^{1 *}$ Sonny Andrianto ${ }^{1}$ \\ ${ }^{1}$ Faculty of Psychology and Socio-Cultural Sciences, Universitas Islam Indonesia, Yogyakarta - Indonesia
}

\begin{abstract}
Anxiety disorders are defined by the World Health Organization (WHO) as the sixth most common non-lethal disease that contributes to a decline in global health. In emerging adulthood, which is the developmental stage of individuals aged $18-25$, anxiety is the most common disorder. This study aims to determine the relationship between materialism and anxiety mediated by self-esteem in emerging adulthood in Yogyakarta, Indonesia. Data were collected through the quota sampling technique and involved 332 emerging adults aged 18-25, consisting of 69 men and 263 women. Measurements were made using the Materialistic Value Scale of Richins and Dawson, the Rosenberg Self-Esteem Scale, and the Beck Anxiety Inventory. The scales were distributed through an online questionnaire. Hypothesis testing was conducted using mediation regression analysis with the causal step method. The results show that all the regression paths were significant, indicating that self-esteem partially mediated the relationship between materialism and anxiety $(B=0.055$, $\mathrm{p}<.01$ ). The findings provide an overview of the dynamics of early adult individual anxiety related to materialism and self-esteem.
\end{abstract}

Keywords: anxiety; emerging adulthood; materialism; self-esteem

\begin{abstract}
Abstrak: Gangguan kecemasan ditetapkan oleh World Health Organization (WHO) sebagai penyakit tidak mematikan ke-6 yang menyebabkan menurunnya kesehatan global. Pada masa emerging adulthood, kecemasan merupakan gangguan yang paling umum terjadi. Emerging adulthood merupakan tahap perkembangan individu usia 18-25 tahun. Penelitian ini bertujuan untuk mengetahui hubungan antara materialisme dan kecemasan yang dimediasi oleh self-esteem pada emerging adulthood di Yogyakarta. Pengambilan data dilakukan melalui teknik quota sampling dan melibatkan 332 emerging adulthood berusia 18-25 tahun yang terdiri atas 69 laki-laki serta 263 perempuan. Pengukuran dilakukan menggunakan Materialistic Value Scale dari Richins dan Dawson, Rosenberg Self-Esteem Scale dari Rosenberg, dan Beck Anxiety Inventory dari Beck. Skala-skala tersebut disebarkan melalui kuisioner daring. Uji hipotesis menggunakan analisis regresi mediasi dengan metode causal step. Hasil penelitian menunjukkan bahwa semua jalur regresi bernilai signifikan sehingga self-esteem memediasi secara parsial hubungan antara materialisme dan kecemasan $(B=0,055, p<0,01)$. Hasil Hasil ini memberikan gambaran dinamika kecemasan individu dewasa awal yang terkait materialisme dan self-esteem.
\end{abstract}

Kata Kunci: emerging adulthood; kecemasan; materialisme; self-esteem *Corresponding Author: Fuad Nashori (e-mail: fuadnashori@uii.ac.id), Faculty of Psychology and Socio-Cultural Sciences,
Universitas Islam Indonesia, Jl. Kaliurang Km 14, 5 Sleman Yogyakarta 55584, Indonesia. 


\section{Introduction}

World Health Organization (WHO) anounced that anxiety disorder ranked the sixth among global non-fatal health problems. WHO also estimated that in 2015 people with anxiety disorder accounted for $3.6 \%$ of the total country population data (WHO, 2017).

Kessler et al. (2005) state that anxiety disorders are the most prevalent mental problem afflicting individuals at some point in their lifetime. The prevalence of anxiety tends to be higher during emerging adulthood in comparison with the other life stages (Arnett et al., 2014; Arnett \& Mitra, 2018). Arnett and Schwab (2012) report that more than half of emerging adults feel some kind of anxiety. In light of this, Kessler et al. (2005) explain that the most common psychiatric problems afflicting emerging adults are anxiety disorders. This shows that emerging adults are susceptible to these disorders.

Emerging adulthood is defined as the period that lasts from ages 18 to 25 and characterizes bachelors/single individuals who are enjoying the freedom and exploring an abundance of choices in their life (Mcmillin, 2017). Arnett (2004) defines emerging adulthood as the period that bridges the gap between adolescence and young adulthood. Emerging adults are so busy exploring so many career opportunities and various forms of relationship that they tend to delay marriage and parenthood in their early 20 's.

Emerging adulthood occurs in countries whose population shows the tendency to get married late. Women's average age of marriage in industrialized countries like the United State of America, Japan, and Australia is between 25 and 27 , while the average age for marriage of women living in developing countries like Indonesia,
India, and Brazil is between 19 and 21 . Consequently, emerging adults predominantly live in developing countries' urban areas. Young people in these areas tend to delay marriage and raising children, try to get the highest education, and explore many job options and opportunities (Arnett, 2004).

Interviews held with numerous emerging adults reveal that they suffer from anxiety disorders. The uncertainty that accompanies anxiety causes them to worry so much about their future. Anxiety frequently leads them to fear, panic, and drown themselves in their inner thoughts.

Sullivan (1948) maintains that anxiety can potentially cause disturbances in people's life experiences, so this disorder must be overcome to help them lead a more rewarding life. Fear of uncertainty will force individuals to cocoon themselves in some comfort zone that prevents them from confronting anxiety, and this in turn will prevent them from attaining meaningful experiences and enjoy longer-lasting happiness (Rascovar, 2015). Barry et al. (2013) found that anxiety often inhibits emerging adults' personal growth and development.

According to Kranzler et al. (2019), anxiety which arises in various stages in life is often associated with evasive behaviors, and evasive behaviors during emerging adulthood are potentially detrimental. The route for success in this stage of life requires individuals to perform tasks that stimulate anxiety, like going to college and attending lectures, making marriage proposals and starting a career, building friendship, and many others. These tasks require the willpower to tolerate uncertainty and face the risks of failure, and for emerging adults with anxiety disorders, this can be an intolerable 
exercise. Besides that, instead of learning to take charge of their own lives and stop relying on parents, emerging adults with anxiety disorders frequently get stuck in some quagmire, feeling unprepared, and unwilling to try harder.

Experts are currently still in disagreement about factors that cause anxiety disorders among emerging adults. Twenge (2006) says that emerging adults have been taught to expect more out of life just when good jobs and fancy houses are becoming harder to afford. Emerging adults have been told about this so often that they become anxious and depressed. Arnett et al. (2013) strongly disapprove of Twenge's findings. He asserts that anxiety and depression that haunt emerging adults are triggered by individuals' search for self-identity, and this commonly happens in their romantic lives and workplace.

Nevid, Rathus, and Greene (2005) indicate four factors of anxiety, and one of them has its humane aspect. Humanistic theoreticians have it that anxiety takes its roots in an individual's social repression. In this case, anxiety surfaces when a conflict or discrepancy between an individual's true inner self and their social mask affects their awareness. Kasser (2002) shows that this discrepancy characterizes materialistic individuals. Highly materialistic individuals mostly suffer from self-discrepancy -- or a huge difference between their present condition and their desired condition -- and this difference is permanent. Materialistic individuals crave for wealth and possessions, and the ever-present discrepancy keeps them feeling discontented. Even if they get rich and can amass a lot of fortune, they will still crave for more, because material success makes them feel good about themselves. This kind of satiation does not last very long and that individual will again go into another cycle of discontent.
In Islamic terms, materialistic lifestyle and orientation are called hubb dunyā (Mujib, 2006). Prophet Muhammad (peace be upon him) once said:

"This wealth is (like) green and sweet (fruit), and whoever takes it without greed, Allah will bless it for him, but whoever takes it with greed, Allah will not bless it for him." (HR alBukhari, narrated by Hakim ibn Hizam).

Allah SWT said in QS. al-Hadīd (57) verse 20:

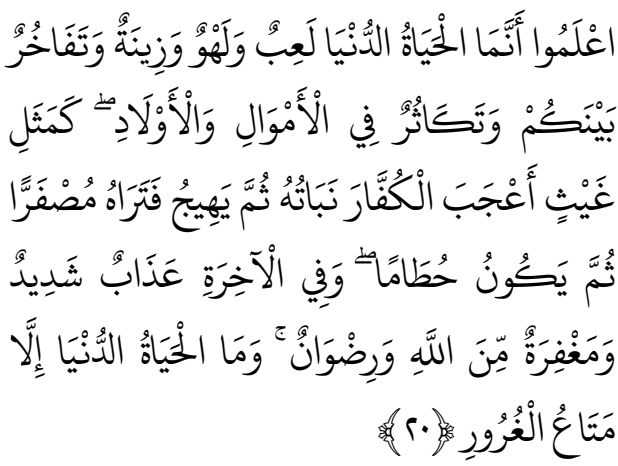

20. Know that the worldly life is only playing and amusement, pomp and mutual boasting among you, and rivalry in respect of wealth and children. [It is] the likeness of vegetation after rain, thereof the growth is pleasing to the farmer; afterward it dries up and you see it turning yellow; then it becomes straw. But in the Hereafter [there is] a severe torment and forgiveness from Allah and good pleasure. And the life of this world is only a deceiving enjoyment.

In this verse, Allah enunciates the indisputable truth that worldly life and happiness are nothing more than profanity and that those things will not last. People who gravitate to worldly life are misleading themselves, blissfully ignorant of yet another life beyond our physical world.

Emerging adults nowadays are passionately embracing materialism as the value of paramount importance in their lives. Smith et al. (2011) state that the vast majority of emerging 
adults nowadays show a proclivity for materialism and consumptivism. Research conducted at Cooperative Institutional Research Programme at UCLA concluded that college students today work hard to gain 'financial achievement' instead of seeking to 'develop a meaningful philosophy of life' like what their predecessors did back in the 1960's (Dreher, 2019). The authors talked to three emerging adults in Yogyakarta about their hopes for the next ten years, and they pointed out that financial success was the most important thing they were after. Their responses show beyond doubt that materialism is now widely spread among youngsters.

Richins and Dawson (1992) define materialism as an individual's primary focus on wealth as the main source of happiness and success. Kasser and Ahuvia (2002) found that avaricious people suffer a lot more from mental health problems compared to less materialistic people. Individuals who greatly value wealth and social status are susceptible to anxiety (Vinayak \& Arora, 2018). This is supported by Emmons (2004) whose research revealed that heavy emphasis on extrinsic materials and goals is closely associated with anxiety, narcissism, depression, and various health issues. This indicates that materialism and anxiety are inextricably linked.
Kasser's (2002) writing shows the importance of considering psychological processes in discussing the relationship between materialism and well-being. Materialistic values will motivate people to choose the wrong path in fulfilling their psychological needs: they prioritize extrinsic goals like wealth, possessions, and popularity, and in so-doing, they compromise their real psychological needs. In line with this, SelfDetermination Theory reveals that unfulfilled basic psychological needs in materialistic individuals will trigger psychological disorders (Brown et al., 2016; Unanue et al., 2017). Landry et al. (2016), support this claim by pinpointing that fulfilled psychological needs are mediators for extrinsic aspirations (like financial success, fame, and self-image) and mental hygiene.

Even so, the number of scientific inquiries on this issue has been limited that we cannot adequately explain the role of psychological fulfillment as the mediator for materialism and poor psychological well-being (Unanue et al., 2017), and this is the reason why the authors opted to use self-esteem -one of human's fundamental psychological needs- as the mediating variable in this study. In this study, we assumed that self-esteem is the mediating variable for materialism and anxiety.

Figure 1

Illustration of the Relationship between Materialism, Self-esteem, and Anxiety

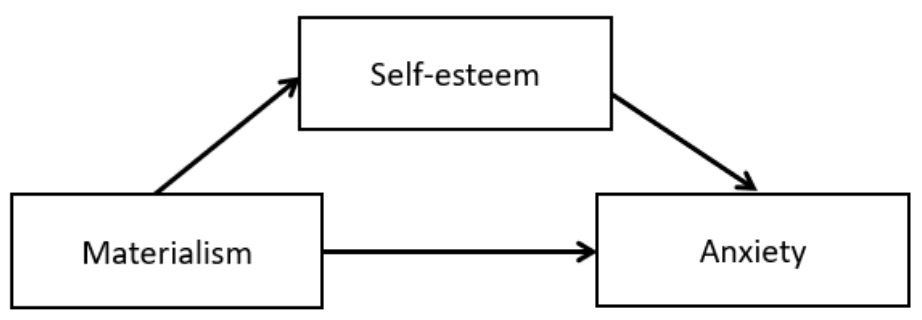


Self-esteem is chosen because of its correlation with materialism and anxiety. Materialism is strongly influencing self-esteem. Studies by Gupta and Singh (2019), Wang et al. (2020), and Jaspers and Pieters (2016) show that the dominance of materialism is detrimental to selfesteem. Kasser's (2002) study is in agreement with this point. His findings show that materialistic individuals often exhibit low selfesteem and believe that their values are commensurate with their achievement and people's admiration. Materialistic individuals often fail to get self-esteem and they frequently need people's praises for support.

When related to anxiety, self-esteem is known to show a negative correlation. Riggs and Han (2009) claim that low self-esteem is associated to anxiety and is the predictor for anxiety among emerging adults. Pertinently, Leary and MacDonald (in Mruk, 2013) through their study found that in comparison to those with high self-esteem, individuals with low selfesteem are prone to getting emotional and more negative conditions, and anxiety is one of them. This claim is relevant to the results of some previous studies conducted by Manna et al. (2016) and Carvalho et al. (2016), which reveal that self-esteem is negatively correlated to anxiety.

Based on the above explanations, this research aimed to find out the mediating effect of self-esteem on the correlation between emerging adults' materialism and anxiety. This research sought to establish the mediating role of selfesteem for materialism and anxiety (major hypothesis). Further, this study aimed to affirm the following minor hypotheses: 1) Negative correlation between materialism and selfesteem, 2) Negative correlation between self- esteem and anxiety, and 3) positive correlation between materialism and anxiety.

\section{Method}

Respondents of this study were carefully selected people who fit the criteria of emerging adulthood, namely: a) college students who were enrolled in a state or private universities in Yogyakarta Region, b) aged between 18 and 25, c) females and males, and d) unmarried. For sampling purposes, we used quota sampling. The total number of respondents in this study was 332 emerging adults.

This quantitative study used a survey or a cross-sectional method. Data on anxiety were collected using Destyani's (2018) adapted version of Beck Anxiety Inventory (BAI). This scale consists of 21 items that include the subjective, neurophysiologic, and autonomic aspects. Using this scale (in the form of an online questionnaire) respondents were asked to evaluate themselves based on how often they experience the sensations specified in the scale's items (for example increased heartbeat; tension). The BAI discriminant index fluctuated ranged between 0.32-0.665 and had the Cronbach Alpha reliability coefficient of 0.872 .

To measure the respondent's materialism, Nugraha's (2017) adaptation of the Materialistic Value Scale (MVS) was used. The scale contains 15 items that are focused on the aspects of achievement, achievement as an instrument for attaining happiness and achievement to defines success. Using this scale, respondents were asked to evaluate themselves based on the extent of their agreement with the statement in the scale's items (for example, I admire people who own expensive homes, cars, and clothes; Some of the most important achievements in life include acquiring 
material possessions). The MVS discriminant index ranged from 0.288 to 0.666 giving the Cronbach alpha reliability coefficient of 0.84 .

Furthermore, Novara's (2018) adaptation of the Rosenberg Self-esteem Scale (RSES) was used to test the aspects of self-competence dan selfliking. Using this scale, the respondents were asked to evaluate themselves based on the extent of their agreement with the feelings described in the items (for example: On the whole, I am satisfied with myself; I take a positive attitude toward myself). The index for RSES discriminant items ranged between 0.361 and 0.662 giving the Cronbach alpha reliability coefficient of 0.804 .

Regression analysis was used to measure the mediating variable. This research used a causal step method aided by SPSS (Statistic Program Social Science) version 20.0 for Windows. Meanwhile, the significance of the indirect effects of the mediating variable was measured using a normal theory approach (i.e the Sobel Test). This analysis was highly instrumental in explaining the mediating role of self-esteem for the relation- ship between materialism and anxiety among emerging adults.

\section{Results}

The results indicated that the effect of an independent variable (materialism) on the dependent variable (anxiety) $\mathrm{Bc}=0.190$. After the mediating variable was introduced, the value decreased into $\mathrm{Bc}^{\prime}=0.135$ which indicated the effect of materialism on anxiety was reduced by $0.055(\neq 0)$, which further showed the decreasing effect of materialism on anxiety when self-esteem was introduced as a mediator. The decrease in $B$ value from $c$ to $c$ indicated the partial mediation of the variable. Based on this finding the authors suggested that self-esteem partially mediated the correlation between materialism and anxiety by 0.055 .

The significance of the indirect effect was measured using the Sobel Test formula. Table 2 shows the result of the above measurement: $\mathrm{p} 2$ tailed of $.0099(\mathrm{p}<.01)$.

Table 1

Hypothesis Test Results

\begin{tabular}{lccc}
\hline \multicolumn{1}{c}{ Variable } & $\mathrm{B}$ & $\mathrm{p}$ & Category \\
\hline Path a & -0.060 & .008 & Significant \\
Path b & -0.963 & .000 & Significant \\
Path c & 0.190 & .000 & Significant \\
Path c' & 0.135 & .008 & Significant \\
\hline
\end{tabular}

$\begin{aligned} \text { Explanation: } & \\ \text { Path a } & =\text { Materialism*self-esteem } \\ \text { Path b } & =\text { Self-esteem*anxiety } \\ \text { Path c } & =\text { Materialism*anxiety } \\ \text { Path c' } & =\text { Materialism*anxiety (by controlling self-esteem) }\end{aligned}$


Figure 2

Regression Analysis without Mediators

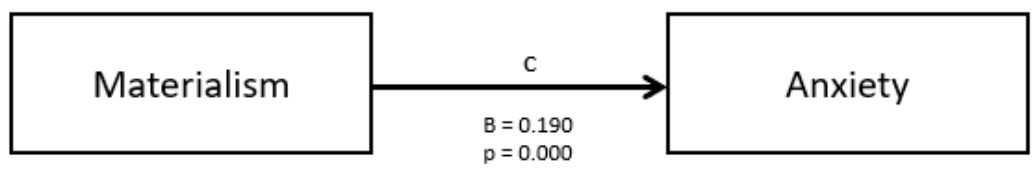

Figure 3

Regression Analysis with Self-esteem as Mediator

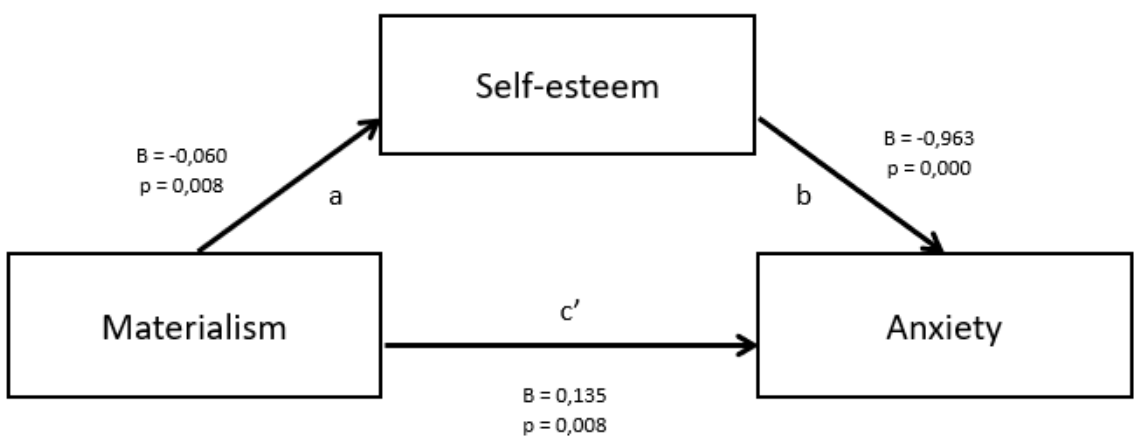

Table 2

Significance of Indirect Effect

\begin{tabular}{clcl}
\hline $\mathrm{p}(2$-tailed $)$ & Category & $\mathrm{p}(1$-tailed $)$ & Category \\
\hline 0.0099 & Significant & 0.005 & Significant \\
\hline
\end{tabular}

However, since the results showed a positive direction, the p-value then reduced to $\mathrm{p}$ 1-tailed of .005 ( $\mathrm{p}<.01)$. This shows that the mediating role of self-esteem on the relationship between materialism and anxiety is significant. In other words, the main hypothesis about the mediating role of self-esteem on materialism and anxiety is accepted.

The results also indicated that there was a negative correlation between materialism and self-esteem ( $\mathrm{Ba}=-0.060 ; \mathrm{p}=.008)$ which showed a significant negative correlation between materialism and self-esteem. $\mathrm{H} 1$ was accepted. In addition, a negative correlation between selfesteem and anxiety was also found $(\mathrm{Bb}=-0.963 ; \mathrm{p}$ $=.000$ ) self-esteem. Therefore, $\mathrm{H} 2$ has also accepted self-esteem. Lastly, a positive and significant correlation was indicated between materialism and anxiety $(\mathrm{Bc}=0.190 ; \mathrm{p}=.000)$. Therefore, $\mathrm{H} 3$ was accepted.

Regression analysis of the mediating variable showed three types of role or effect that represent the role of independent variables on the dependent variables: the direct effect, indirect 
effect, and the total effect (Urbayatun \& Widhiarso, 2013). The direct effect refers to the role of independent variables on the dependent variable (path c'). The indirect effect refers to the role of an independent variable on the dependent variable through mediating variable (path a $x$ path b or $\mathrm{c}-\mathrm{c}^{\prime}$ ), while the total effect refers to the result of direct effect, Besides, the indirect effect [path c + (path a $\times$ path b)]. As a result, it indicated that materialism has a direct effect (path $\left.\mathrm{c}^{\prime}\right)$ of 0.135 on anxiety $\left(\mathrm{Bc}^{\prime}=0.135 ; \mathrm{p}=\right.$ .008). The indirect effect (path a $\times$ path b or $\mathrm{c}-\mathrm{c}^{\prime}$ ) was 0.055 . The total effect (direct effect + indirect effect) was $B c^{\prime}=0.135$ and $\mathrm{Bab}=0.055$ gives the value for total effect of 0.190 .

\section{Discussion}

This study aimed to find out the mediating effect of self-esteem on emerging adults' materialism and anxiety. The main hypothesis of this study is: "there is a positive correlation between emerging-adults' materialism and anxiety through the mediating role of selfesteem." Data analysis confirmed that this hypothesis is accepted. Materialism and anxiety are significantly correlated when self-esteem is introduced as the mediating variable.

Self-esteem proves to have partially mediated the positive relationship between materialism and anxiety. This demonstrates that the high value of materialism causes individuals to have low self-esteem, which in turn will trigger anxiety. In line with this, Kasser (2002) suggests that materialism will motivate individuals to fulfill their psychological needs in the wrong way, by focusing their efforts on extrinsic goals like property or wealth, self-image, and popularity in place of self-esteem, which is their essential psychological need. The failure to satisfy the basic psychological needs in materialistic individuals will present psychological disorders like anxiety (Brown et al., 2016; Kasser, 2002; Unanue et al., 2017).

However, the amount of mediation is minimum, albeit significant. In this study, the direct effect outweighs the indirect effect. According to Zhao et al. (2010), this phenomenon points out the presence of the other mediating variables that help to explain the relationship between independent variables and dependent variables; future researchers can use this as the starting point for their studies.

The limited mediating role of self-esteem could be attributable to the fact that materialistic individuals' self-esteem is volatile as a result of their unstable self-concepts (Richins, 2017). The findings of Richin's research reveal the frequently inconsistent relationships between materialism and self-esteem. Out of 14 studies that he had summarized, 5 studies concluded that the relationship between materialism and selfesteem is insignificant. In fact, out of 9 studies that showed the opposite results, only 2 indicated that the significance of the relationship is bigger than -0.2 . This instability possibly shows two different factors that shape the self-concept and self-esteem of materialistic individuals: their material possessions (Richins, 2017) and people's admiration and praises (Kasser, 2002). This inconsistency causes individuals' selfesteem to change over time, depending on their moods and the effects of their daily life experience (Richins, 2017).

In addition to that, respondents' demographic factors could also negatively contribute to the mediating factors. In this case, our respondents are college students who currently live in the Special Region of Yogyakarta. The local culture may have 
influenced the way they evaluated themselves (how they scored themselves in the scale). Maneechukate (2018), sees that Indonesian culture discourages flagrant display of pride and encourages people to show humility. The problem is, humility makes it hard for individuals to talk openly about their personal opinions (Bukhori, 2016). Among Javanese, self-restraint, and the proclivity to show cool reticence has been so deeply ingrained and makes it extremely difficult for outsiders to fathom their true feelings (Soehadha, 2014). Those cultural influences may explain why native Javanese tend to refrain from displaying or expressing their pride. And this may have been the reason behind our respondents' reluctance to openly respond to the questionnaires, especially to the items measuring their self-esteem. Cogently, Gebauer et al. (2008) state that brazen display or expression of positive self-evaluation (explicit high self-esteem) is deemed a serious violation against some Oriental cultures. According to Gebauer et al. (2008), the use of implicit self-esteem scales may provide alternative solutions. Future researchers may consider using implicit self-esteem scales for Indonesian respondents, especially Javanese individuals.

In addition to the major hypothesis, this study presents three minor hypotheses. The first minor hypotheses on the negative correlation between materialism and self-esteem is accepted. Findings of the study show that more materialistic individuals have lower self-esteem, and vice versa. This is supported by Gupta and Singh (2019), Wang et al. (2020), and Jaspers and Pieters (2016) whose studies reveal that higher materialism positively correlates with low selfesteem. Richins's (2017) statement echoes the above conclusion: Highly materialistic people often have low self-esteem, and they hold on to the false belief that their values are defined by their achievements and people's praise and admiration (Kasser, 2002). However, the influence of materialism on decreasing selfesteem is relatively minimal albeit significant. We have previously pointed out that the negligible correlation between materialism and self-esteem may have been the result of materialistic individuals' unstable self-concept which in turn manifests itself in their dynamic self-esteem (Richins, 2017).

The second minor hypothesis on the correlation between low self-esteem and the higher incidence of anxiety (and the opposite) was accepted. This finding is relevant to Riggs and Han (2009) claim that low self-esteem is among the strong predictors for emerging adult's anxiety. Leary and MacDonald's (in Mruk, 2013) study found that compared to those having high selfesteem, individuals with low self-esteem tend to get more emotional and expose themselves to negative situations, among which is anxiety. Leary and MacDonald also have the view that low self-esteem is the characteristic or dignostic criterion of mental disorders like anxiety. Consequently, efforts to help emerging adults' increase their self-esteem can be made to minimize the likelihood of anxiety.

The third minor hypothesis on the positive correlation between materialism and anxiety was accepted (this hypothesis also contains the direct effect that explains the effect of independent variables on the dependent variables), thus the high level of materialism is always associated with a high level of anxiety, and vice versa. This conclusion is in agreement with Vinayak and Arora's (2018) findings, that individuals who put great value on material wealth and social status fall victim to anxiety. Kasser (2002) shares the 
view that great emphasis on materialistic values will not help individuals attain happiness and well-being. Instead, they get a lot of anxiety, diminishing vitality, low satisfaction in life, and very little pleasant emotions.

The overwhelming influence of materialism on anxiety proves that the current anxiety afflicting the emerging adults (our respondents) is the consequence of their materialism. This agrees with Smith et al. (2011) that the majority of today's emerging adults show a strong tendency toward materialism dan consumptivism, and the recent survey launched by UCLA showed that currently, college students put 'financially rich' above everything else (Dreher, 2019). That explains why Kessler et al. (2005) reveal that the most prevalent psychiatric problem haunting emerging adults today is an anxiety disorder. The high emphasis on materialistic value may have been responsible for the onset of anxiety during emerging adulthood.

Hopefully, the above explanations help illustrate our effort to describe the dynamics of anxiety afflicting emerging adults which stems from the positive correlation between their materialism and self-esteem. It was stated earlier in this paper that anxiety disorder among emerging adults is prevalent. This study explains the importance of material wealth, fame, and image and the feeling of being minimal contribution to the onset of anxiety.
This study also has its limits, and chief among them is the single mediating variable that we use in studying and explaining the phenomenon. Theoretically, human's psychological needs are pivotal in mediating the relationship between materialism and anxiety. This study, however, only introduced a single variable, which is selfesteem, while in reality human's psychological needs are manifested in various variables. Inevitably, the findings of this study show that the direct effect outweighs the indirect effect, and this indicates the presence of the other mediating variables (psychological needs) that needs exploring. Besides that, this study used explicit scales of self-esteem which may be inappropriate since the context of Indonesian culture necessitates the use of more subtle or implicit scales of self-esteem that helps us to better describe our respondents' self-esteem.

\section{Conclusion}

The research findings indicate that the major and minor hypotheses are accepted. Self-esteem has proved to partially mediate the correlation between materialism and anxiety among emerging adults. The amount of mediation, however, is minimal, which may have been caused by our research participants' unstable self-esteem and the dominance of local culture that prevents the respondents from frankly and freely responding to our explicit self-esteem scale.[]

\section{References}

Arnett, Jeffrey J., Žukauskienè, R., \& Sugimura, K. (2014). The new life stage of emerging adulthood at ages 18-29 years: Implications for mental health. The Lancet Psychiatry, 1(7), 569-576. https://doi.org/10.1016/S2215-0366(14)00080-7

Arnett, Jeffrey Jensen. (2004). Emerging adulthood: The winding road from the late teens through the twenties. Oxford University Press. 
Arnett, Jeffrey Jensen, \& Mitra, D. (2018). Are the features of emerging adulthood developmentally distinctive? A comparison of ages 18-60 in the United States. Emerging Adulthood. https://doi.org/10.1177/2167696818810073

Arnett, Jeffrey Jensen, \& Schwab, J. (2012). The Clark University poll of emerging adults: Thriving, struggling, \& hopeful (Issue December).

Arnett, Jeffrey Jensen, Trzesniewski, K. H., \& Donnellan, M. B. (2013). The dangers of generational mythmaking. Emerging Adulthood, 1(1), 17-20. https://doi.org/10.1177/2167696812466848

Barry, C. M. N., Nelson, L. J., \& Christofferson, J. L. (2013). Asocial and afraid: An examination of shyness and anxiety in emerging adulthood. Journal of Family Studies, 19(1), 2-18. https://doi.org/10.5172/jfs.2012.1979

Brown, K. W., Kasser, T., Ryan, R. M., \& Konow, J. (2016). Materialism, spending, and affect: An eventsampling study of marketplace behavior and its affective costs. Journal of Happiness Studies, 17(6), 2277-2292. https://doi.org/10.1007/s10902-015-9694-9

Bukhori, B. (2016). Kecemasan berbicara di depan umum ditinjau dari kepercayaan diri dan keaktifan dalam organisasi kemahasiswaan. Jurnal Komunikasi Islam, 6(1), 158-186. https://doi.org/10.15642/JKI.2016.6.1.158-186

Carvalho, I. G., Bertolli, E. dos S., Paiva, L., Rossi, L. A., Dantas, R. A. S., \& Pompeo, D. A. (2016). Anxiety, depression, resilience and self-esteem in individuals with cardiovascular diseases. Revista Latino-Americana de Enfermagem, 24(e2836). https://doi.org/10.1590/1518-8345.1405.2836

Destyani, A. R. (2018). Pengaruh terapi zikir terhadap tingkat kecemasan pada pasien stroke. Universitas Islam Indonesia.

Dreher, D. (2019). Why Do So Many College Students Have Anxiety Disorders? Psychology Today. https://www.psychologytoday.com/intl/blog/your-personal-renaissance/201903/why-doso-many-college-students-have-anxiety-disorders

Emmons, R. A. (2004). Personal goals, life meaning, and virtue: Wellsprings of a positive life. In Flourishing: Positive psychology and the life well-lived (pp. 105-128). American Psychological Association. https://doi.org/10.1037/10594-005

Gebauer, J. E., Riketta, M., Broemer, P., \& Maio, G. R. (2008). "How much do you like your name?" An implicit measure of global self-esteem. Journal of Experimental Social Psychology, 44(5), 13461354. https://doi.org/10.1016/j.jesp.2008.03.016

Gupta, N., \& Singh, R. A. (2019). Role of materialism in influencing self-esteem. SIS Journal of Projective Psychology \& Mental Health, 26(1), 51-55.

Jaspers, E. D. T., \& Pieters, R. G. M. (2016). Materialism across the life span: An age-period-cohort analysis. Journal of Personality and Social Psychology, 111(3), 451-473. https://doi.org/10.1037/pspp0000092

Kasser, T. (2002). The high price of Materialism. MIT Press.

Kasser, T., \& Ahuvia, A. (2002). Materialistic values and well-being in business students. European Journal of Social Psychology, 32(1), 137-146. https://doi.org/10.1002/ejsp.85

Kessler, R. C., Berglund, P., Demler, O., Jin, R., Merikangas, K. R., \& Walters, E. E. (2005). Lifetime prevalence and age-of-onset distributions of DSM-IV disorders in the national comorbidity survey replication. Archives of General Psychiatry, 62(6), 593. https://doi.org/10.1001/archpsyc.62.6.593 
Kranzler, A., Elkins, R. M., \& Albano, A. M. (2019). Anxiety in emerging adulthood: A developmentally informed treatment model. In Pediatric Anxiety Disorders (pp. 499-519). Elsevier. https://doi.org/10.1016/B978-0-12-813004-9.00022-0

Maneechukate, S. (2018). Karakter masyarakat Indonesia berdasarkan peribahasa. Indonesian Language Education and Literature, 4(1), 91-102. https://doi.org/10.24235/ileal.v4i1.2628

Manna, G., Falgares, G., Ingoglia, S., Como, M. R., \& De Santis, S. (2016). The relationship between selfesteem, depression and anxiety: Comparing vulnerability and scar model in the Italian context. Mediterranean Journal of Clinical Psychology, 4(3), 2282-1619. https://doi.org/10.6092/2282$1619 / 2016.4 .1328$

Mcmillin, J. L. (2017). The paradox of choice in emerging adulthood: Anxiety and ambivalence (Issue August). Bowling Green State University.

Mruk, C. J. (2013). Self-esteem and positive psychology: Research, theory, and practice (4th ed.). Springer Publishing Company.

Mujib, A. (2006). Teori kepribadian perspektif psikologi Islam. PT RajaGrafindo Persada.

Nevid, J. S., Rathus, S. A., \& Greene, B. (2005). Psikologi abnormal (R. Medya \& W. C. Kristiaji (Eds.); J. Murad (Trans.)). Erlangga.

Novara, A. (2018). Hubungan antara body image dissatisfaction dengan self- esteem pada pegawai bank. Universitas Islam Indonesia.

Nugraha, A. W. S. (2017). Hubungan antara materialisme dan kepuasan perkawinan pada individu suamiistri. Sanata Dharma University.

Rascovar, A. M. (2015). Ego development and anxiety during emerging adulthood. Smith College.

Richins, M. L. (2017). Materialism pathways: The processes that create and perpetuate materialism. Journal of Consumer Psychology, 27(4), 480-499. https://doi.org/10.1016/j.jcps.2017.07.006

Richins, M. L., \& Dawson, S. (1992). A consumer values orientation for materialism and its measurement: Scale development and validation. Journal of Consumer Research, 19(3), 303316. https://doi.org/10.1086/209304

Riggs, S. A., \& Han, G. (2009). Predictors of anxiety and depression in emerging adulthood. Journal of Adult Development, 16(1), 39-52. https://doi.org/10.1007/s10804-009-9051-5

Smith, C., Christoffersen, K., Davidson, H., \& Herzog, P. S. (2011). Lost in transition: The dark side of emerging adulthood. Oxford University Press.

Soehadha, M. (2014). Wedi isin (takut malu); ajining diri (harga diri) orang Jawa dalam perspektif wong cilik (rakyat jelata). Religi Jurnal Studi Agama-Agama, 10(1), 1-11. https://doi.org/10.14421/rejusta.2014.1001-01

Sullivan, H. S. (1948). The meaning of anxiety in psychiatry and in life. Psychiatry, 11(1), 1-13. https://doi.org/10.1080/00332747.1948.11022666

Thibault Landry, A., Kindlein, J., Trépanier, S.-G., Forest, J., Zigarmi, D., Houson, D., \& Brodbeck, F. C. (2016). Why individuals want money is what matters: Using self-determination theory to explain the differential relationship between motives for making money and employee psychological health. Motivation and Emotion, 40(2), 226-242. https://doi.org/10.1007/s11031-015-9532-8

Twenge, J. M. (2006). Generation me: Why today's young Amerincans are more confident, assertive, entitled - and more miserable than ever before. Atria Paperback. 
Unanue, W., Rempel, K., Gómez, M. E., \& Van den Broeck, A. (2017). When and why does materialism relate to employees' attitudes and well-being: The mediational role of need satisfaction and need frustration. Frontiers in Psychology, 8(Oct), 1-15. https://doi.org/10.3389/fpsyg.2017.01755

Urbayatun, S., \& Widhiarso, W. (2013). Variabel mediator dan moderator dalam penelitian psikologi kesehatan masyarakat. Jurnal Psikologi, 39(2), 180-188. https://doi.org/10.22146/jpsi.6985

Vinayak, S., \& Arora, A. K. (2018). Social anxiety and peer pressure as predictors of materialism among adolescents. IMPACT: International Journal of Research in Humanities, Arts and Literature, 6(6), 513-524.

Wang, R., Liu, H., \& Jiang, J. (2020). Does socioeconomic status matter? Materialism and self-esteem: Longitudinal evidence from China. Current Psychology. https://doi.org/10.1007/s12144-02000695-3

World Health Organization. (2017). Depression and other common mental disorders: Global health estimates. World Health Organization.

Zhao, X., Lynch, J. G., \& Chen, Q. (2010). Reconsidering Baron and Kenny: Myths and Truths about Mediation Analysis. Journal of Consumer Research, 37(2), 197-206. https://doi.org/10.1086/651257 
This page has been intentionally left blank. 